\title{
Seed recovery and germination of reseeded species fed to cattle
}

\author{
K. M. DOUCETTE, K. M. WITTENBERG, AND W. P. McCAUGHEY
}

K. M. Doucette(undergrad student) and K. M. Wittenberg (Professor), Department of Animal Science, University of Manitoba, Winnipeg Manitoba, R3T 2N2. W. P. McCaughey (Scientist), Agriculture and Agri-Food Canada, Research Centre, P. O. Box JOOQA, Brandon, Manitoba R7A 5Y3. Corresponding author: K. M. Wittenberg

\section{Abstract}

Cattle have the potential to act as a low cost alternative for seed dissemination of valuable native species. Data collected from this trial was used to compare seed recovery, rate of passage and viability following ingestion and excretion of 7 plant species. Woods rose (Rosa woodsii Lindl.), snowberry (Symphoricarpos albus L.), purple prairie clover (Petalostemom purpureum Vent.), birdsfoot trefoil (Lotus corniculatus $\mathbf{L}$.), western wheatgrass (Pascopyrom smithii Rydb A. Love, formerly known as Agropyron smithii Rydb.), green needlegrass (Nassella viridula Trin.), and yellow coneflower (Ratibida columnifera Nutt.) seed was used in the study. Two steers were fed a seed-free diet consisting of fresh cut vegetative Kentucky bluegrass (Poa pratensis $\mathbf{L}$.)-alfalfa (Medicago sativa $\mathrm{L}$.) forage. Following a 13 day adjustment period to the diet, steers were fed a single dose of a known number of seeds, and total feces collection was conducted for 168 hours post dosing. Fecal sub-samples were subjected to a stacked screen washing procedure for seed recovery and analysis. Seeds from both pre- and post-ingestion were tested for hard seededness, firm ungerminated seed, and germination. Seed recovery varied between seed types, ranging from $5.9 \%$ of total ingested seed for western wheatgrass, to $86.3 \%$ for Woods rose. Excretion patterns for ingested seed varied between seed types, with $50 \%$ of excreted seed being recovered between 30 to 54 hours post-dosing. Seed ingestion and passage through the digestive tract reduced viability. Cattle dissemination of viable seeds (as a \% of ingested) such as Woods rose (77.4) and snowberry (69.3), would be a feasible method of delivering large numbers of viable seeds onto selected areas. Dissemination of birdsfoot trefoil (17.5), green needlegrass (11.9), and purple prairie clover (7.2), yellow coneflower (3.8), and western wheatgrass (1.3), using cattle would be less efficient, implementation should be based on seed access and cost.

Key Words: seed dispersal, cattle digestion, passage, dissemination, seed survival

Many seed dispersal mechanisms exist for plants using wind, water, and animals as the dispersal agents. Researchers have noted that successful dissemination of seeds through cattle feces is common (Welch 1985, Pleasant and Schlather 1994). Early work by Ridley (1930) identified 124 species for which successful seed dispersal by cattle was documented.

Joint funding provided by Ducks Unlimited and Agriculture and Agri-Food Canada's Matching Investment Initiative Fund.

Manuscript accepted 29 Oct. 00.

\section{Resumen}

El ganado tiene el potencial de actuar como una alternativa de bajo costo para la diseminación de semilla de especies nativas valiosas. Los datos colectados de este ensayo fueron utilizados para comparar la recuperación de semilla, la tasa de paso y la viabilidad de la semilla después de ingerida y excretada y se estudiaron 7 especies de plantas. En este experimento se utilizo semilla de "Woods rose" (Rosa woodsii Lindl.), "Snowberry" (Symphoricarpos albus L.), "Purple prairie clover" (Petalostemom purpureum Vent.), "Birdsfoot trefoil" (Lotus corniculatus L.), "Western wheatgrass" (Pascopyrom smithii Rydb A. Love, formerly known as Agropyron smithii Rydb.), "Green needlegrass" (Nassella viridula Trin.) y "Yellow coneflower" (Ratibida columnifera Nutt.). Dos novillos se alimentaron con una dieta libre de semilla consistente de forraje fresco de "Kentucky bluegrass" (Poa pratensis L.) cortado en etapa vegetativa + "Alfalfa" (Medicago sativa L.). Después de un periodo de 13 días de adaptación a la dieta, los novillos se alimentaron con una sola dosis de un número conocido de semilla y se condujo una colección total de heces durante 168 horas después de administradas las semillas. Submuestras fecales se sometieron a un procedimiento de lavado a través de mallas apliadas para recuperar la semilla y su análisis. Antes y después de la ingestión se evaluaron las semillas para determinar su dureza, semillas sin germinar y germinación. La recuperación de semilla difirió entre tipos de semillas, variando en un rango de $5.9 \%$ del total de la semilla ingerida del "Western wheatgrass" al $86.3 \%$ para el "Woods rose". Los patrones de excreción de la semilla ingerida variaron entre tipos de semilla, el $50 \%$ de recuperación de la semilla excretada ocurrió entre las 34 a 54 horas de consumida la semilla. La ingestión de semilla y su paso a través del tracto digestivo reducen la viabilidad. La diseminación de semilla viable por el ganado (como \% del ingerido) sería, en el caso de "Woods rose (77.4) y "Snowberry" (69.3), un método factible para depositar grandes cantidades se semilla viable en áreas seleccionadas. Para el caso de "Birdsfoot trefoil" (17.5), “Green needlegrass" (11.9), "Purple prairie clover" (7.2), "Yellow coneflower" (3.8) y "Western wheatgrass" (1.3) la diseminación de semilla utilizando ganado sería menos eficiente y la implementación debe basarse en el acceso a la semilla y su costo.

Burton and Andrews (1948) and Lyon et al. (1992) examined the dissemination of weed seeds by cattle and observed that this method of dissemination is successful enough to be a cause for concern in monoculture farming or managed ecosystems. Many studies have examined the mechanism of weed seed dispersal via 
the animal digestive tract, but less research has examined animals as a vehicle for the dissemination of desirable species (Simao Neto et al. 1987, Barrow and Havstad 1992, Ocumpaugh et al. 1993).

Seeding desired species into select areas is highly desirable, often leading to an improvement in forage productivity, wildlife habitat, soil, and water quality. When attempting to revegetate large inaccessible areas of land, mechanical seeding methods may have limited success or may not be possible (Barrow and Havstad 1992), while manual reseeding is extremely time consuming and expensive (Ocumpaugh et al. 1996). Cattle ingestion and excretion of seed as a method of seed dispersal has potential to transport large numbers of seeds and deposit them in a germinable form into an environment suitable for establishment. Ocumpaugh et al. (1996) suggested the advantages of fecal seeding for species compatible with this method of dispersal include higher seedling emergence, establishment and growth. Reintroduction of native plant species for improvement of wildlife habitat is being considered on selected sites across the Canadian Prairie. The objective of this study was to determine whether this method is biologically feasible for revegetation programs involving Woods rose (Rosa woodsii Lindl.), snowberry (Symphoricarpos albus L.), purple prairie clover (Petalostemom purpureum Vent.), birdsfoot trefoil (Lotus corniculatus L.), western wheatgrass (Pascopyrom smithii Rydb. A. Love, formerly known as Agropyron smithii Rydb.), green needlegrass (Nassella viridula Trin.), and yellow coneflower seeds (Ratibida columnifera Nutt.). These plants, with the exception of birdsfoot trefoil, represent native forbs, grasses, shrubs and woody plants in the Northern Great Plains.

\section{Materials and Methods}

Seeds from Woods rose, purple prairie clover, snowberry and green needlegrass were hand harvested and cleaned by air separation and hand sieving (Fig. 1). Seed from yellow coneflower was hand harvested and did not require further cleaning. Western wheatgrass was mechanically harvested and cleaned by sieving. Birdsfoot trefoil was purchased as cleaned seed from a commercial seed supplier. The seed was harvested from several locations in southern Saskatchewan at $50^{\circ} 26^{\prime} \mathrm{N}$, $103^{\circ} \mathrm{W}$. Seeds were hand mixed using methods described by the Association of

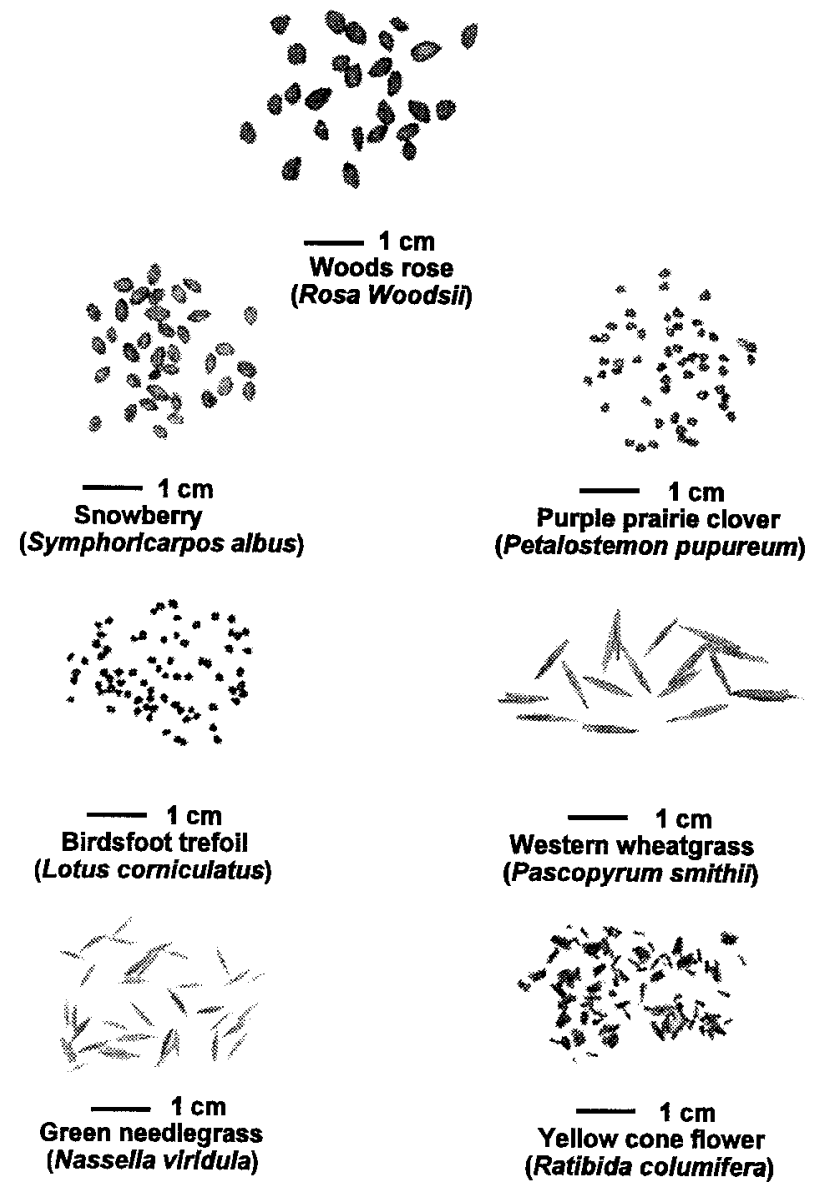

Fig. 1. Sample of seeds fed to growing steers.

Official Seed Analysts (1993, method 2.2). Sub-samples were obtained for seed characterization and animal dosing. Seed density and number of seeds $\mathrm{g}^{-1}$, were established by counting seeds of a known weight using 5 replicates. Quantity of seeds to be fed was determined by the seed size, and ease with which it could be identified in the feces.

Three Holstein steers, weighing $580 \pm$ $9 \mathrm{~kg}$, and accustomed to ground barley supplementation were housed in floor pens for 11 days while adapting to a diet of green chopped vegetative Kentucky bluegrass (Poa pratensis L.)-alfalfa (Medicago sativa $\mathrm{L}$.) forage mixture (70:30, DM basis) which was fed $1.5 \%$ of body weight. Fresh water and cobalt-iodized salt licks were available ad libitum. Steers were relocated to metabolism crates on day 12 and allowed to adjust to the crates. Seed from the 7 plant species were fed to each steer on day 14 of the trial. Animals were handled in accordance with guidelines established by the Canadian Council on Animal Care (CCAC 1993).

Green chop forage was harvested every second day using a Haldrup harvester and was stored in large plastic containers in a cooler kept at $3^{\circ} \mathrm{C}$. Forage was harvested at the vegetative stage to prevent mature seed ingestion by the steers. Fresh forage was used to create a rumen environment similar to that of grazing animals.

Samples of the fresh forage were obtained at each feeding and were stored $\left(-20^{\circ} \mathrm{C}\right)$ for dry matter (DM), crude protein $(\mathrm{CP})$, neutral detergent fiber (NDF), and acid detergent fiber (ADE) determination at a later date. Samples were composited, placed in a forced air oven at $60^{\circ} \mathrm{C}$ for 48 hours, then ground to pass a $1 \mathrm{~mm}$ screen prior to analysis for DM, CP (Kjeldahl method, Method No. 984.13, AOAC 1990; using a Tecator 1030 analyzer), NDF (Goering and Van Soest 1970) and ADE [Method No. 973.18, AQAC 1990; using ANKOM's Fiber Analyzer \#F200 (Fairport, N.Y.)].

Animals were maintained in metabolism crates at the time of seed dosing and during the 8 day total fecal collection period. Steers were exercised twice, at 50 and at 98 hours post dosing during the fecal collection period. Feces excreted during the exercise period was collected. Steers were 
fed half of their daily forage allotment the evening of day 13 and on day 14 at 0920 hours the steers were offered 1,854 $\mathrm{g}$ of seeds mixed in $1 \mathrm{~kg}$ of ground barley. The seed mixture was left in the feed bunks for 6 hours. After 6 hours the remaining seedbarley mixture was collected, weighed, and analyzed for DM and seed content. Green chop forage was offered at $1.5 \%$ $\mathrm{BW}$ thereafter, and for the following 7 days.

Feces were collected in plastic trays. Total feces in the tray was weighed, mixed and sub- sampled at $6,12,24,30,36,42$, $48,54,60,66,72,84,96,108,120,132$, 144,156 , and 168 hours after the seed was first offered to the steers.

Feces collected from each steer within a period from the 6 hour to 72 hour collections were mixed for 10 minutes on low speed in a Hobart mixer (Model lt 600, spec 6345, Hobart Manufacturing Co. Ltd., Toronto, Canada) prior to sampling. The subsequent 12 hour collection samples from each steer were mixed individually for 15 minutes prior to sampling. Five, $200 \mathrm{~g}$ aliquots were sampled for each steer by collection time. One aliquot was retained for DM determination, 2 for germination assays, 1 for seed recovery estimates and another was stored at $-20^{\circ} \mathrm{C}$ for nitrogen determination at a later date. Seed offered, seed not consumed, and feces DM determinations were conducted after 48 hours drying in a forced air oven at $60^{\circ} \mathrm{C}$. Dried fecal samples were ground to pass a $1 \mathrm{~mm}$ screen and sent to Norwest Labs, 545 University Crescent, Winnipeg, Manitoba, for nitrate-N analysis
(Greenberg et al. 1995, method 4500-N).

Seed recovery was conducted using a method similar to Jones and Bunch (1977). A $200 \mathrm{~g}$ fecal sample was placed in a 2 liter container. One liter of water was added to the feces and gently stirred to create a slurry. The slurry was then poured through a series of 3 stacked sieves with decreasing apertures of $2 \mathrm{~mm}, 1 \mathrm{~mm}$, and $0.42 \mathrm{~mm}$ (Mesh \#10,18 and 40, U. S. Standard Sieve Series, Endecotts (Filters) Limited, London, England). Sieves were rinsed with water until the majority of the fine particles washed away. The seeds remained in the sieves along with the larger particles of digesta. The residue from each screen was transferred separately to trays lined with paper towel, and dried for approximately 24 hours at $28^{\circ} \mathrm{C}$ in a forced air oven. Dried samples were sieved gently through a $2 \mathrm{~mm}$ sieve to break up any clumps.

A forced air aspirator (E. L. Ericson Products, Brookings, S. D. USA, Model $\mathrm{D}$, Serial \#175) with controllable airflow was used to separate the finer particles from the dried seeds. All fractions of the dried feces were carefully examined with the use of a magnifying lamp and stereoscope. All recognizable seeds, regardless of physical damage, were retrieved and separated according to seed type. Seed counts were conducted using the sorted material.

Based on total fecal collection and seed densities from the $200 \mathrm{~g}$ sub sample, seed recovery at time $(\mathrm{t})$ was calculated as:

((Seeds $\div 200$ g sub-sample) $\mathrm{x}$ (total $\mathrm{g}$ fecal output (time t) $) \div$ original num- ber of seeds ingested)*100.

Seed viability was determined to be the sum of hard seeds or firm ungerminated seeds and the normal seedlings emerged as a percent of total seed. One hundred seeds representing each species at each collection time were sent to Accutest Seed Labs (Box 579, Rivers, Manitoba, Canada, ROK IXO, Marie Greeniaus, accredited seed analyst) for germination analysis based on standard germination trials by the Association of Official Seed Analysts (1993). Seeds were tested for viability, percent hard seededness (legumes and shrubs), percent firm ungerminated seed (grasses, forbs, and woody plants), and ability to germinate. Some fecal samples did not yield 100 seeds per species, in which case all collected seeds were submitted.

The effect of seed type on seed recovered, viable seed recovered and normal seed germination was analyzed as a oneway analysis of variance using SAS Institute, Inc. (1988). Statistical differences among treatment means were tested using the Student-Newman-Keuls test when seed type differences were observed. Correlations were performed for seed viability vs retention time in the digestive tract for each seed type.

\section{Results and Discussion}

Woods rose, the heaviest of the 7 seeds, had a seed weight of $13.6 \mathrm{mg}$, and is characterized as a smooth, round unhulled shrub seed which exhibited a high degree of hard seededness (Table 1). Snowberry,

Table 1. Characteristics of seed fed to growing steers.

\begin{tabular}{|c|c|c|c|c|c|c|}
\hline Scientific Name & Common Name & Plant Type & $\begin{array}{l}\text { 100-seed } \\
\text { weight }\end{array}$ & Viability $^{1}$ & $\begin{array}{l}\text { Hard seed }^{2}(\mathrm{H}) \text { I Firm } \\
\text { ungerminated } \\
\text { ung }(\mathrm{F})\end{array}$ & $\begin{array}{c}\text { Normal } \\
\text { seedlings }\end{array}$ \\
\hline & & & $(\mathrm{mg})$ & $(\%)$ & $(\%)$ & $(\%)$ \\
\hline Rosa woodsii & Woods rose & Shrub & 1360 & 100 & $100 \mathrm{H}$ & 0 \\
\hline Symphoricarpos albus & Snowberry & Woody plant & 460 & 94 & $94 \mathrm{~F}$ & 0 \\
\hline Petalostemon puipureum & $\begin{array}{l}\text { Purple prairie clover } \\
\text { Forb/legume }\end{array}$ & Warm season & 170 & 91 & $9 \mathrm{H}$ & 82 \\
\hline Lotus corniculatus & Birdsfoot trefoil & Legume & 120 & 89 & $21 \mathrm{H}$ & 68 \\
\hline Pascopyrum smithii & Western wheatgrass & $\begin{array}{l}\text { Cool season } \\
\text { Grass }\end{array}$ & 340 & 65 & $52 \mathrm{~F}$ & 13 \\
\hline Nassella viridula & Green needlegrass & $\begin{array}{l}\text { Cool season } \\
\text { Grass }\end{array}$ & 170 & 68 & $42 \mathrm{~F}$ & 26 \\
\hline Ratibida columnifera & Yellow coneflower & Forb & 70 & 44 & $1 \mathrm{~F}$ & 43 \\
\hline
\end{tabular}

Viability; percent hard seed or firm ungerminated + percent normal seedlings

${ }^{2}$ Hard seed; seed which remains hard at the end of the prescribed test period because it has not absorbed water due to an impermeable seed coat (Association of Official Seed Analysts 1993)

${ }^{3}$ Firm Ungerminated Seed; seed which has failed to germinate but has imbibed moisture and appears firm, fresh, and capable of germination at the end of the prescribed test period and under prescribed test conditions. Such seeds may be viable but dormant (Association of Official Seed Analysts 1993)

${ }^{4}$ Normal seedlings; Seedlings possessing the essential structures that are indicative of their ability to produce useful mature plants under favorable field conditions (Association of Official Seed Analysts 1993) 
had a seed weight of $4.6 \mathrm{mg}$, and is classified as a woody plant. It had a relatively smooth tear-shaped seed without a hull or awns and exhibited a high degree of firm ungerminated seeds. Purple prairie clover and birdsfoot trefoil, both legumes, had round, smooth seeds without hulls or awns. Seeds of those species weighed 1.7 $\mathrm{mg}$ and $1.2 \mathrm{mg}$, respectively. Both purple prairie clover and birdsfoot trefoil seeds had a low level of hard seeds. Birdsfoot trefoil seed can be as high as $90 \%$ hard seed, but scarification during seed harvest and processing will reduce the percent hard seed (Beuselinck and Grant 19957 Western wheatgrass and green needlegrass are both cool season grasses with elongated seeds. Western wheatgrass produced a bulky, hulled seed with a weight of $3.3 \mathrm{mg}$ and exhibited $52 \%$ firm ungerminated seeds while green needlegrass had a smooth seed with a seed weight of $1.7 \mathrm{mg}$ and exhibited $42 \%$ firm ungerminated seeds. Yellow coneflower, a forb, had hulled tear-shaped seeds with a bulky hull and a seed weight of $0.7 \mathrm{mg}$. Yellow coneflower exhibited very low levels of firm ungerminated seeds.

In general, the Woods rose, snowberry, purple prairie clover and birdsfoot trefoil seeds were rounder than the elongated western wheatgrass, and green needlegrass (Figure 1). Woods rose, snowberry, purple prairie clover, birdsfoot trefoil, and green needlegrass seeds were smoother and more dense than the western wheatgrass and yellow coneflower seeds, which exhibited a builder hull.

The green chopped vegetative Kentucky bluegrass-alfalfa forage fed to steers aver- aged $32 \% \mathrm{DM}$ and contained $13.6 \% \mathrm{CP}$, $55.5 \% \mathrm{NDF}$ and $36.4 \%$ ADF, DM basis. Seed consumption varied considerably among the 3 steers. One steer, \#27, consumed $484 \mathrm{~g}$ or $17 \%$ of the $2,8 \mathrm{~S} 4 \mathrm{~g}$ seedbarley mixture offered. A second steer, \#36, rapidly consumed $2,822 \mathrm{~g}$ or $99 \%$ of the seed barley mixture, whereas the third steer, \#29, consumed $2,029 \mathrm{~g}$ or $71 \%$ of the seed barley mixture within 6 hours. If animal dispersal of seeds is to be used as a tool for revegetation using a dose feeding system, a high 23 degree of variation can be expected in seed intake by the animals that are to serve as "seeders", even though they had been accustomed to grain supplementation. This problem can be avoided by dosing the animals with gelatin capsules containing the desired seed, however, that option is not considered suitable when larger volumes of seed are being considered as in this study. With the limited number of animals used in our study, it is not possible to evaluate the causes of animal-to-animal variation.

Animals in the current trial were intake restricted to $50 \%$ of the regular intake of $1.5 \%$ body weight on a DM basis in the 24 hours immediately prior to feeding the seed-barley mixture. More rapid and more uniform intake may have been realized if a more severe feed restriction had been imposed. A severe feed restriction was not used in the current trial because it would have influenced the rate of passage. Due to low ingestion of seed, data were not collected for steer \#27.

Woods rose $(86 \pm 3 \%)$ and snowberry $(84 \pm 3 \%)$ had the highest $(\mathrm{P}<0.05)$ recovery, as a percentage of seed ingested
(Table 2). Recovery of seed did not differ $(\mathrm{P}>0.05)$ for western wheatgrass $(6 \pm$ $3 \%)$, yellow coneflower $(18 \pm 3 \%)$, purple prairie clover $(26 \pm 3 \%)$, green needlegrass $(26 \pm 3 \%)$, and birdsfoot trefoil (27 $\pm 3 \%$ ). Woods rose and snowberry had a greater percentage of hard seed or firm ungerminated seed (Table 1), which appeared to result in a greater post ingestion recovery than purple prairie clover and birdsfoot trefoil. These findings are in accordance with Gardener et al. (1993) who observed a drop in seed recovery in feces from 80 to $6 \%$ as hard seed content declined from $95 \%$ in Leucaena leucocephala (leucaena) to $6 \%$ in Trifolium repens (white clover) of the ingested seed. Ocumpaugh (1994) noted that most cool season grasses tend to exhibit poor seed survival when exposed to ruminant digestion, an observation we found for western wheatgrass.

Rate of seed passage, expressed cumulatively, as time taken to recover $50 \%$ of seed excreted, 22 revealed that for all seed types $50 \%$ of the recovered seed was excreted within 30 to 54 hours afterseed was offered to steers (Fig. 2 and 3). Peak excretion rate of Woods rose, snowberry and green needlegrass seeds occurred from 30 to 36 hours post-ingestion. Peak excretion rate of purple prairie clover, and birdsfoot trefoil seeds occurred from 24 to 36 hours post-ingestion. Peak excretion rate of yellow coneflower and western wheatgrass seeds occurred from 42 to 48 hours and 48 to 54 hours post-ingestion, respectively.

Seed viability was lower after ingestion of the seeds (Table 2). Residence time in

Table 2. Total seed ingested, seed removed from feces, and germination results of recovered seeds when fed to growing steers.

\begin{tabular}{|c|c|c|c|c|c|c|c|}
\hline Seed Type & Anaimal & Total seed & $\begin{array}{l}\text { Seed recovered, } \\
\text { ingested }\end{array}$ & $\begin{array}{l}\text { Total viable }{ }^{1} \\
\% \text { of intake }\end{array}$ & $\begin{array}{l}\text { Viable seed } \\
\text { recovered } \\
\text { recovered see }\end{array}$ & $\begin{array}{c}\text { Total } \\
\text { normal } \\
\% \text { of intake }\end{array}$ & $\begin{array}{c}\text { Nomral } \\
\text { seedlings } \\
\text { seedlings }\end{array}$ \\
\hline \multicolumn{8}{|l|}{$\%$ of intake } \\
\hline Woods rose & $\begin{array}{l}\# 29 \\
\# 36\end{array}$ & $\begin{array}{c}\text { (No.) } \\
19,147 \\
29,705\end{array}$ & $\begin{array}{l}(\%) \\
81.5 \\
91.0\end{array}$ & $\begin{array}{c}\text { (No.) } \\
12,829 \\
26,083\end{array}$ & $\begin{array}{l}(\%) \\
67.0 \\
87.8\end{array}$ & $\begin{array}{c}\text { (No.) } \\
0 \\
0\end{array}$ & $\begin{array}{c}(\%) \\
0 \\
0\end{array}$ \\
\hline Snowberry & $\begin{array}{l}\# 29 \\
\# 36\end{array}$ & $\begin{array}{l}23,887 \\
29,840\end{array}$ & $\begin{array}{l}81.0 \\
87.3\end{array}$ & $\begin{array}{l}13,812 \\
24,065\end{array}$ & $\begin{array}{l}57.8 \\
80.7\end{array}$ & $\begin{array}{l}0 \\
0\end{array}$ & $\begin{array}{l}0 \\
0\end{array}$ \\
\hline Purple prairie clover & $\begin{array}{l}\# 29 \\
\# 36\end{array}$ & $\begin{array}{l}130,458 \\
148,918\end{array}$ & $\begin{array}{l}16.7 \\
34.5\end{array}$ & $\begin{array}{c}3,893 \\
16,996\end{array}$ & $\begin{array}{c}3.0 \\
11.4\end{array}$ & $\begin{array}{l}1176 \\
1936\end{array}$ & $\begin{array}{l}0.9 \\
1.3\end{array}$ \\
\hline Birdsfoot trefoil & $\begin{array}{l}\# 29 \\
\# 36\end{array}$ & $\begin{array}{l}128,796 \\
148,937\end{array}$ & $\begin{array}{l}16.7 \\
36.3\end{array}$ & $\begin{array}{l}11,016 \\
39125\end{array}$ & $\begin{array}{c}8.6 \\
26.3\end{array}$ & $\begin{array}{c}645 \\
2667\end{array}$ & $\begin{array}{l}0.5 \\
1.8\end{array}$ \\
\hline Western wheatgrass & $\begin{array}{l}\# 29 \\
\# 36\end{array}$ & $\begin{array}{l}117,678 \\
149,522\end{array}$ & $\begin{array}{l}7.1 \\
4.6\end{array}$ & $\begin{array}{l}1,666 \\
1,732\end{array}$ & $\begin{array}{l}1.4 \\
1.2\end{array}$ & $\begin{array}{c}205 \\
92\end{array}$ & $\begin{array}{l}0.2 \\
0.1\end{array}$ \\
\hline Green needlegrass & $\begin{array}{l}\# 29 \\
\# 36\end{array}$ & $\begin{array}{l}125,633 \\
149,396\end{array}$ & $\begin{array}{l}29.6 \\
22.1\end{array}$ & $\begin{array}{l}15,105 \\
17,606\end{array}$ & $\begin{array}{l}12.0 \\
11.8\end{array}$ & $\begin{array}{l}2063 \\
1435\end{array}$ & $\begin{array}{l}1.6 \\
1.0\end{array}$ \\
\hline Yellow coneflower & $\begin{array}{l}\# 29 \\
\# 36\end{array}$ & $\begin{array}{l}129,445 \\
149,378\end{array}$ & $\begin{array}{l}19.6 \\
16.3\end{array}$ & $\begin{array}{l}5076 \\
5552\end{array}$ & $\begin{array}{l}3.9 \\
3.7\end{array}$ & $\begin{array}{l}4479 \\
3495\end{array}$ & $\begin{array}{l}3.5 \\
2.3\end{array}$ \\
\hline
\end{tabular}

${ }^{\mathrm{T}}$ Viability; percent hard seed or firm ungerminated + percent normal seedlings. 


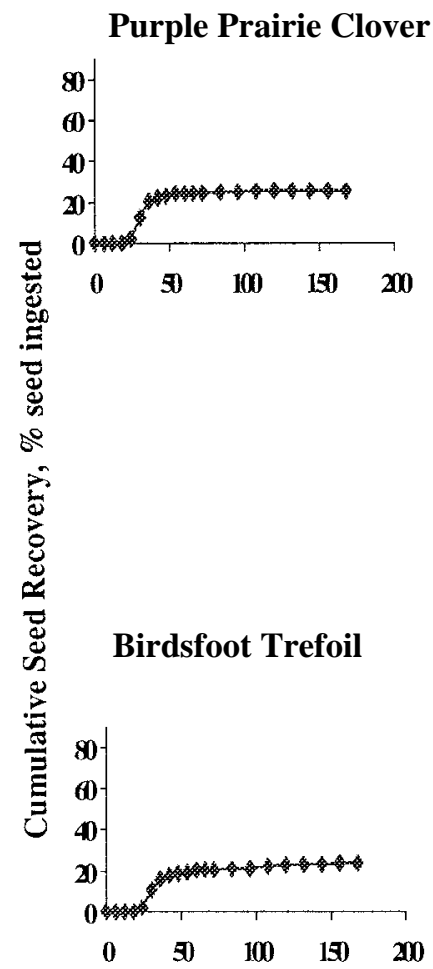

Hours Post Feeding

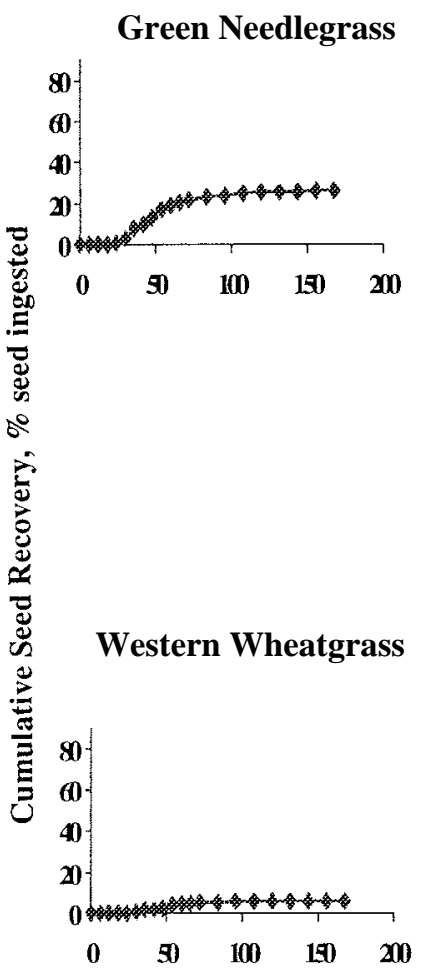

Hours Post Feeding

Fig. 2. Fecal recovery over a 7-day period for legume and grass seeds ingested as a single dose by steers. $n=2$

the digestive tract did decrease $(\mathrm{P}<0.05)$ seed viability for western wheatgrass, green needlegrass and yellow coneflower; however, this trend was not apparent for the other seed types (Table 3). Some of the recovered Woods rose seed showed signs of physical damage, probably due to mastication. Recovered snowberry seed showed minimal signs of physical damage, however, some seed coats were removed and the seeds appeared lighter in color. When recovered purple prairie clover seed was examined it was observed that there was extensive physical damage to the seed. Many seed coats were removed and some of the seeds began germination in vivo. When the recovered birdsfoot trefoil seed was examined physical damage, such as seed coat loss, was observed. Recovered seed from western wheatgrass and green needlegrass did not have visible physical damage. Examination of the recovered yellow coneflower seed revealed that the majority of the seeds appeared to have had the hulls removed but no other physical damage was visible.

Although total seed recovered declined dramatically by 120 hours post ingestion, viability of seed recovered thereafter was high for some seed types. For example, 6 snowberry seeds recovered from the 144 hour fecal sample had $100 \%$ viable firm ungerminated seed. From the same fecal collection time, birdsfoot trefoil had 11 seeds recovered with $89 \%$ viable hard seed, and purple prairieclover had nine seeds with $88 \%$ viable hard seed. Simao Neto et al. (1987) have also reported thatthe percentage of viable hard seed recovered increased with time. This may be because non-viable seed with a long residence time in the digestive tract was digested. Gardener et al. (1993) also reported that for some intact seed, percent viability and hard seededness increased with time spent in the digestive tract.

The residence time of seed in the ruminant digestive tract has been negatively correlated with seed germinability (Simao Neto et al. 1987, Ocumpaugh and Swakon 1993). Woods rose, snowberry, purple prairie clover, birdsfoot trefoil, and green needlegrass seeds had smoother, denser seeds and also exhibited faster rates of passage than the less dense western wheat- grass and yellow coneflower seeds. This is in accordance with Gardener et al. (1993) who speculated that smooth seeds have a faster rate of passage because they more readily separate from the fibrous digesta in the rumen than do rough surfaced seeds. Gardener et al. (1993) also indicated that density and seed size are positively correlated to rate of passage, and Ocumpaugh et al. (1991) indicated that for grasses, seed density was positively related to seed survival. Simao Neto et al. (1987) indicated that rate of passage for longer grass seeds was slower than for more compact seeds. Both green needlegrass and western wheatgrass seeds have elongated shapes, with western wheatgrass being longer. These differences in smoothness, density, and seed shape may have resulted in the slower rate of passage for both western wheatgrass, and yellow coneflower seeds. Overall, seed size and density were not positively correlated $(\mathrm{P}>0.05)$ to passage rate, as heavy large seeds such as Woods rose had similar passage rates to the smaller lighter seeds of purple prairie clover and birdsfoot trefoil (Table 1). This corre-

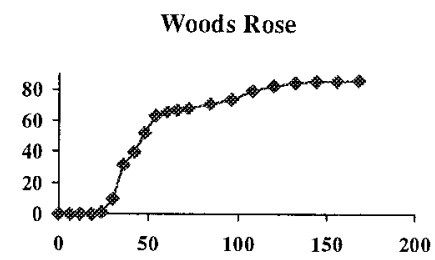

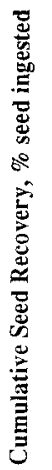

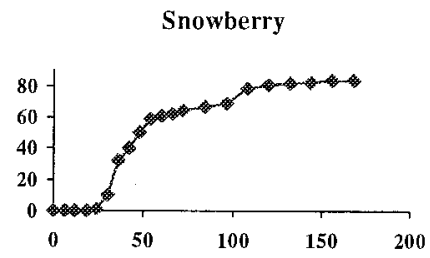

Yellow Coneflower

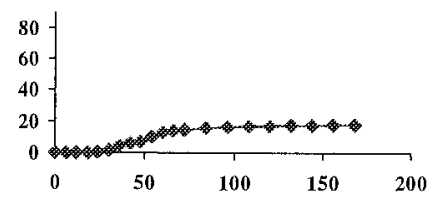

Hours Post Feeding

Fig. 3. Fecal recovery over a 7-day period of forb and shrub seeds ingested as a single dose by steers. $n=2$ 
Table 3. Effect of retention time in the digestive tract on viability $(\%)$ of seed recovered from feces. $n=2$

\begin{tabular}{|c|c|c|c|c|c|c|c|}
\hline \multirow[b]{2}{*}{ SeedType } & \multicolumn{6}{|c|}{ Retention time, days } & \multirow[b]{2}{*}{7} \\
\hline & 1 & 2 & 3 & 4 & 5 & 6 & \\
\hline & \multicolumn{7}{|c|}{ (- - - - - } \\
\hline Woods Rose & 100.0 & 96.0 & 92.0 & 95.0 & 98.5 & 91.5 & 81.5 \\
\hline Snowberry & 100.0 & 93.5 & 83.0 & 86.5 & 74.0 & 100.0 & 64.0 \\
\hline Purple prairie clover & 9.0 & 2.0 & 73.0 & 63.0 & 78.0 & 89.0 & NA \\
\hline Birdsfoot trefoil & 6.5 & 52.5 & 70.0 & 71.5 & 91.5 & 82.0 & 100.0 \\
\hline Western wheatgrass & 60.0 & 35.0 & 30.0 & 39.0 & NA & NA & NA \\
\hline Green needlegrass & 68.0 & 63.0 & 60.0 & 42.5 & 51.0 & 42.0 & 11.0 \\
\hline Yellow coneflower & 58.0 & 46.5 & 9.5 & 6.0 & 0.0 & 0.0 & NA \\
\hline
\end{tabular}

NA No seeds were recovered from fecal subsamples taken in that 24 hour collection period.

sponds to work by Ocumpaugh et al. (1991) who found all seeds had similar passage rates, but contradicts work by Gardener et al. (1993) who found that large, dense seeds with low levels of hard seededness had the fastest passage rate, and high levels of hard seededness resulted in a longer mean retention time in vivo.

Excretion of viable seeds, as a percent of intake, was greatest $(\mathrm{P}<0.05)$ for Woods rose $(77 \pm 3 \%)$ which had an initial viability of $100 \%$ (Table 1) and also had a high proportion of hard seed, and for snowberry $(69 \pm 3 \%)$ which had a high percent firm ungerminated seed pre-ingestion (Table 2). Viable seeds excreted, $\%$ of total ingested seed, did not differ $(\mathrm{P}>$ 0.05 ) among the other seed types. Excretion of viable seeds was least for western wheatgrass, which had an initial viability of $65 \%$. Western wheatgrass had $52 \%$ firm ungerminated seed pre-ingestion (Table 1) and excreted seed exhibited 1.3 $\pm 3 \%$ viability (Table 2 ). Loss of seed viability was greatest for purple prairie clover which had apre-ingestion viability of $91 \%$ (Table 1) and a post digestion viability of $7.2 \pm 3 \%$ (Table 2). Purple prairie clover had $9 \%$ hard seed pre-ingestion (Table 1). Birdsfoot trefoil had $21 \%$ hard seed preingestion (Table 1) and excreted seed exhibited $17 \pm 3 \%$ viability (Table 2 ) Green needlegrass had $42 \%$ firm ungerminated seed pre-ingestion (Table 1) and excreted seed exhibited $12 \pm 3 \%$ viability (Table 2). Yellow coneflower had 1\% firm ungerminated seed pre-ingestion (Table 1) and excreted seed exhibited $3.8 \pm 3 \%$ viability (Table 2). The percentage of firm ungerminated or hard seededness was positively correlated $(\mathrm{P}<0.05)$ with seed viability post-ingestion, however, only $70 \%$ of the variation can be accounted for by measuring these seed characteristics. Low levels of seed viability for yellow coneflower and western wheatgrass could be related to increased residence time in the digestive tract and subsequent exposure to digestive processes.

It is difficult to speculate as to the cause of changes in seed viability. Jansen (1984) argues that not all plants have seeds that are adapted for seed dispersal by ungulates and would, therefore, not have the physical adaptations to survive mastication, and exposure to microbial, acid and enzyme digestion. For example, during feces collection, purple prairie clover seeds were observed to have germinated in the fresh dung. It is possible that these seeds may have begun to germinate in vivo and had these seeds been allowed to remain in the manure they would most probably have desiccated as the manure dried. This observation coupled with the low viability of recovered seed suggests that purple prairie clover would not be a species that would be suited to dispersal using grazing cattle.

Normal seedlings are defined as seedlings possessing the essential structures that are indicative of their ability to produce useful mature plants under favorable field conditions (Association of Official Seed Analysts 1993). Normal seedlings, as a percent of recovered seed, decreased due to ingestion for all seed types $(\mathrm{P}<0.05$, Table 2$)$ except for Woods rose and snowberry where germination remained zero for both pre- and post-ingestion germination trials. Lengthy dormancy periods are required for Woods rose and snowberry (Gerling et al. 1996).' Results from this trial suggest that digestion does not scarify the seed or hasten germination. Yellow coneflower had low percent seed recovery and viability but had the highest $(\mathrm{P}<0.05)$ percent of normal seedlings, expressed as a percentage of intake $(2.9 \pm 0.2 \%$, Table 2$)$.

These results coincide with studies by Yamada and Kawaguchi (1972) who reported a remarkable decrease in viability after passage through the digestive tract of cattle for ladino clover (Trifolium repens L., $72 \%$ ), sub clover (Trifolium subterraneum, 51\%), orchardgrass (Dactylis glomerata L., 74\%), and Italian ryegrass (Lolium multiflorum Lam., 73\%). Simao Netoetal. (1987) and Gardener et al. (1993) reported variable results for a range of grass and legume seeds tested. Quinn et al. (1994) found that the passage of buffalograss (Buchloe dactyloides Nutt.) diaspores through cattle had a positive effect on germination. Therefore, it can be concluded that the effects of seed ingestion on germination vary greatly between plant species.

It is apparent that dissemination by cattle of hard seeded, or firm ungerminated species, such as Woods rose and snowberry, is a feasible method of delivering large numbers of viable seeds onto selected areas. If cattle were used to disseminate purple prairie clover, birdsfoot trefoil, western wheatgrass, green needlegrass, and yellow coneflower seeds, much smaller numbers of viable seeds would be disseminated. Results for the mechanically harvested and cleaned birdsfoot trefoil may be improved when animals graze seed heads as hard seed content will increase. It would be necessary to evaluate the benefits of this low cost seeding alternative in light of the expense of the seed lost to digestion. Consumption of seeds by cattle is not an effective method of increasing the viability of the Great Northern Plains native species that were tested in this study or birdsfoot trefoil.

\section{Literature Cited}

Association of Official Analytical Chemists (AOAC) 1990. Official methods of analysis. K. Helrich, ed. $15^{\text {th }}$ ed. AGAC, Arlington, Virg.

Association of Official Seed Analysts 1993. Rules for testing seeds. Volume 16, Number 3. AOSA, Bozeman, Mont.

Barrow, J. R. and K. M. Havstad. 1992. Recovery and germination of gelatin-encapsulated seeds fed to cattle. J. Arid Environ. 22:395-399.

Beuselinck,P.R. and W.F. Grant. 1995. Birdsfoot trefoil p. 237-248 In: Forages Volume 1, An introduction to grassland agriculture. Eds. R.F. Barnes, D.A. Miller, C.J. Nelson. Iowa State University Press, Ames, Ia.

Burton, G. W. and J. S. Andrews. 1948. Recovery and viability of seeds of certain grasses and les-pedeza passed through the bovine digestive tract. J. Agr. Res. 76:95-103. 
Canada Council on Animal Care. 1993. Guide to the care and use of experimental animals. Volume 1, ED. Olfert, B.M. Cross and A.A. McWilliam, eds CCAC, Ottawa, Ontario.

Gardener, C. J., J. G. Mclvor, and A. Jansen. 1993. Passage of legume and grass seeds through the digestive tract of cattle and their survival in feces. J. Appl. Ecol. 30:63-74.

Gerling, H. S., M. G. Willoughby, A. Schoepf, K. E. Tannas, and C. A. Tannas. 1996. A guide to using native plants on disturbed lands. Alberta Agriculture, Food and Rural Development, and Alberta Environmental Protection. Edmonton, Alberta.

Goering, H. K. and P. J. Van Soest. 1970. Forage fiber analysis (apparatus, reagents, procedures, and some application). Agr. Handb. No. 379. Agr. Res. Serv., USDA, Washington, DC.

Greenberg, A. E., A. D. Eaton, and L. S. Clesceri, eds. 1995. Standard methods for the examination of water and waste water. American Public Health Assoc., Washington D.C.

Jansen, D. H. 1984. Dispersal of small seeds by big herbivores: foliage is the fruit. The Amer. Nat. 123:338-353.
Jones, R. M. and G.A. Bunch. 1977. Sampling and measuring the legume seed content of pasture soils and cattle feces. CSIRO Division of Tropical Crops and Pastures, Tropical Agron. Techn. Memoran. No. 7.

Lyon, D. J., D. D. Baltensperger, and I. G. Rush. 1992. Viability, germination, and emergence of cattle-fed jointed goat grass seed. J. Prod. Agr. 5:282-285.

Ocumpaugh, W.R. 1994. Some practical aspects of distributing forage seeds with livestock. American Forage and Grassl. Conf. March 6-10. Lancaster, Penn.

Ocumpaugh, W.R. and D. H. D. Swakon. 1993. Simulating grass seed passage through the digestive system of cattle: A laboratory technique. Crop Sci. 33:1084-1090

Ocumpaugh, W. R., J. W. Stuth, and S. Archer. 1993. Recovery and germination of switchgrass seed fed to cattle. p. 318-319 In: Proc. $17^{\text {th }}$ Internat. Grassl. Congr. Palmerston North, New Zealand. 8-12 Feb. 1993. New Zealand Grassland Assoc.

Ocumpaugh, W. R., S. Archer, and J. W. Stuth, 1996. Switchgrass recruitment from broadcast seed vs. seed fed to cattle. J. Range Manage. 49:368-371.

Ocumpaugh, W. R., J. W. Stuth, and S. Archer. 1991. Using cattle to distribute pasture seeds. p. F40-F49. In: Texas A\&M Univ. Agr. Res. Sta. at Beeville. Information Report 91-1.
Pleasant, J. M. T. and K. J. Schlather. 1994. Incidence of weed seed in cow manure and its importance as a weed source for crop land. Weed Technol. 8:304-310.

Quinn, J. A., D. P. Mowrey, S. M. Emanuele, and R. D. P. Whalley. 1994. The "Foliage is the Fruit" hypothesis: Buchloe Daclyloides (Poaceae) and the shortgrass prairie of North America. Amer. J. Bot. 81:1545-1554.

Ridley, H. N. 1930. The dispersal of plants throughout the world. Clowes and Sons Ltd., London.

SAS Institute, Inc. 1988. SAS user's guide: Statistics. Version 6 ed. SAS institute, Inc. Cary, N.C. 956 p.

Simao Neto, M., R. M. Jones, and D. Radcliff. 1987. Recovery of pasture seed ingested by ruminants. 1. Seed of six tropical pasture species fed to cattle, sheep and goats. Aust. J. Exp. Agr. 27:239-246.

Welch, D. 1985. Studies in the grazing of heather mooreland in north-east Scotland IV. Seed dis-persal and plant establishment in dung. J. Appl. Ecol. 22:461-472.

Yamada, T. and T. Kawaguchi. 1972. Dissemination of pasture plants by livestock 2 . Recovery, viability and emergence of some pasture plant seeds passed through the digestive tract of dairy cows. J. Japan. Soc. Grassl. Sci. 18:16-27. 